\title{
Evaluation of microbial consortia and chemical changes in spontaneous maize bran fermentation
}

\author{
Marilù Decimo ${ }^{1 \dagger}$, Mattia Quattrini ${ }^{2 \dagger}$, Giovanni Ricci ${ }^{2}$, Maria Grazia Fortina ${ }^{2 *} \mathbb{0}$, Milena Brasca ${ }^{1}$, Tiziana Silvetti ${ }^{1}$, \\ Federica Manini ${ }^{2}$, Daniela Erba², Franca Criscuoli ${ }^{2}$ and Maria Cristina Casiraghi ${ }^{2}$
}

\begin{abstract}
Sustainable exploitation of agro-industrial by-products has attracted great interest in cereal bran valorization. In this research, a polyphasic approach has been carried out to characterize maize bran at microbiological and chemical level during a sourdough like fermentation process, in order to enhance its technological and nutritional properties. Autochthonous microbiota was isolated at different refreshment steps and subjected to identification and molecular characterization. Fermentation was characterized by a rapid increase in lactic acid bacteria and yeasts, with a codominance, at the initial stage, of Weissella spp., Pediococcus spp. and Wickerhamomyces anomalus. At the end of the fermentation, a natural selection was produced, with the prevalence of Lactobacillus plantarum, Lactobacillus brevis and Kazachstania unispora. This is the first time that a specific association between $L A B$ and yeasts is reported, during the maize bran fermentation process. Enzymatic activities related to this microbial consortium promoted a "destructuration" of the fiber fraction, an increase in soluble dietary fiber and a reduction of phytic acid content. Our data also evidenced a noticeable increment in ferulic acid. The results obtained indicate that fermentation processes represent an efficient biotechnological approach to increase nutritional and functional potential of maize bran. Moreover, the characterization of microbiota involved in natural fermentation process will allow the selection of specific biotypes, with appropriate metabolic and enzymatic activities, to conduct "tailored" fermentation processes and improve brans or whole-meal flours from both nutritional and technological points of view.
\end{abstract}

Keywords: Maize bran valorization, Spontaneous fermentation, Microbial consortia, Lactic acid bacteria, Yeasts, Bioactive compounds

\section{Introduction}

Cereal bran valorization has, for many reasons, a noticeable interest. The dietary recommendations call for an increased intake of functional foods: by-products generated by cereal agro-industrial sector are rich in dietary fiber, minerals and bioactive compounds and could represent beneficial ingredients for human nutrition. The main reasons behind the low utilization of native brans as ingredient for cereal-based products are due to their

\footnotetext{
*Correspondence: grazia.fortina@unimi.it

${ }^{\dagger}$ Marilù Decimo and Mattia Quattrini contributed equally to this work

${ }^{2}$ Department of Food, Environmental and Nutritional Sciences, University of Milan, Milan, Italy

Full list of author information is available at the end of the article
}

poor safety (heavy metal and mycotoxins), technological (increased dough stickiness, reduced volume) and sensory qualities (dark color, taste, chewy/hard texture) (Rose et al. 2010; Heinio et al. 2016). The spontaneous sourdough-like fermentation process, characterized by a consortium of yeasts and lactic acid bacteria (LAB), has shown to be an interesting pre-treatment in order to ameliorate sensory and textural quality, as well as to improve the microbial safety of bran (Dalié et al. 2010; Manini et al. 2014; Messia et al. 2016). Recently, several studies have shown the ability of many LAB to inhibit mold growth and mycotoxin biosynthesis (Dalié et al. 2010). These data highlight the potential offered by LAB as natural agents for decontamination of food frequently contaminated by toxigenic fungal strains, particularly 
cereals. Moreover, through fermentation, an increased bioavailability of bioactive compounds and a decreased level of some anti-nutritional compounds can be obtained (Katina et al. 2012; Manini et al. 2014).

To date, the majority of published literature in this field regards fermented wheat bran. Little is known about the effects of this "bio-approach" on properties of others cereal, as maize. This cereal and its by-products could represent attractive alternative raw materials for fiber enrichment of gluten-free products. According to A.I.R.E.S (Associazione Italiana Essiccatori Raccoglitori Stoccatori di Cereali e Semi oleosi, http://www.micotossine.it/), about $82 \%$ of maize production is used for animal feed and only $18 \%$ is devoted to human consumption. At the milling stage, dry maize mechanical processing creates whole or fractionated products, accounting about for up to $25 \%$, generally used as animal feed or biofuel. In this context, the valorization of maize by-products as valuable food ingredients to be exploited in the production of new food formulation could represent an opportunity.

Ferulic acid is diffused in cereals and maize bran appears as one of the richer sources, containing about 26-33 g/kg (Zhao and Moghadasian 2008). Moreover, maize bran contains hemicellulose, cellulose and a small amount of lignin, thus representing a source of dietary fiber. The hemicellulosic fraction, generally denominated arabinoxylans (AX), has a particular heterogeneous nature, with extensive cross-linkages between ferulic acid and arabinose/xylose heteropolisaccharides. This particular feature promoted a complex and rigid structure of maize cell wall (Rose et al. 2010). The potential of native microorganisms and their enzymatic activities of increasing the fraction of soluble dietary fibers and the content of free ferulic acid deserves to be tested.

Recently the EFSA Panel published a positive Opinion about the request of an Health Claim related to the positive effects on the post-prandial glycemic and insulinemic responses elicited by water-extractable arabinoxylans (WEAX) (EFSA 2011). This Opinion was founded on results from different studies reporting that this fraction can delay the rate of carbohydrates digestion/absorption, thus positively affecting glucose metabolism ( $\mathrm{Ai}$ and Jaylin 2016; EFSA 2011). Moreover, it is quite recognized in literature that arabino-xylanoligosaccharides (AXOS) and xylan-oligosaccharides (XOS) obtained by the hydrolysis of arabinoxylans present in brans can exert prebiotic properties (Broekaert et al. 2011).

Little data are available in literature on microbial population during maize fermentation. They mainly refer to maize-based spontaneously fermented doughs produced in West African countries (Oguntoyinbo et al. 2011; Okeke et al. 2015; Assohoun-Djeni et al. 2016). Very lacking information exists on microbial population during maize bran fermentation and on their contribution in promoting nutritional and functional properties of this cereal by-product. Thus, this study was performed to characterize maize bran, at microbiological and chemical level during a sourdough like fermentation process.

\section{Materials and methods}

Fermentation process and chemical analyses

Two commercial native maize brans $(\mathrm{C} 1$ and $\mathrm{C} 2$-average particle size 500-600 $\mu \mathrm{m}$-Molino Perteghella, Solarolo di Goito, MN, Italy; Molino Spoletini, Arcevia, AN, Italy) were subjected to spontaneous fermentations (without microbial starters), according to Manini et al. (2014). Fermentation experiments were carried out in duplicate, at $30{ }^{\circ} \mathrm{C}$, through continuous propagation until a stable microbiota was established (12 days). Unfermented samples and fermented bran samples, collected at different refreshment steps were stored at $-20{ }^{\circ} \mathrm{C}$ for further analysis.

Proximate composition, ferulic acid, total (TOTAX) and water-soluble (WEAX) arabinoxylans, were assessed, in duplicate, on native and fermented maize brans as previously reported (Manini et al. 2014).

\section{Evaluation of microbial population}

Using selective media and conditions as previously reported (Manini et al. 2014), we quantified and isolated lactic acid bacteria (LAB), non-lactic acid bacteria (NLAB), yeasts and molds.

For each fermented bran, between 5 and 20 colonies representing all morphologies were picked from the respective plates at the refreshment steps 1,7 and 12 , purified by successive streaking, and stored in glycerol at $-80{ }^{\circ} \mathrm{C}$ for further experimentations. A total of 135 presumptive $\mathrm{LAB}, 93$ yeast isolates, 12 NLAB and three molds were selected and subjected to identification and molecular characterization.

\section{Molecular identification of the isolates}

Total bacterial DNA was extracted from $100 \mu \mathrm{L}$ of an overnight culture, using the Microlysis kit (Labogen, Rho, Italy) following the manufacturer's instructions. For LAB identification, a first clustering step was reached by a PCR amplification of the $16 S-23 S$ rDNA spacer region (RSA). Molecular identification of LAB isolates with different RSA patterns, and NLAB was carried out by partial $16 S$ rDNA gene sequencing, species-specific amplification and/or restriction analysis of the $16 S-23 S$ rDNA spacer region. For the isolated yeasts and molds, total DNA was extracted in a PRECELLYS ${ }^{\circledR}$ 24-DUAL lyser/ homogeniser (Bertin-technologies, Saint Quentin en Yvelines, France) (3 cycles of 30 s, 30-s break) with a mixture of glass beads $(\varnothing<106 \mu \mathrm{m})$. Molecular identification 
was carried out by restriction digestion of the Internal Transcribed Spacer (ITS) and/or partial 26S rDNA gene sequencing. The DNA sequences for the primers used, their corresponding specificities and the thermal cycle parameters employed are reported in Table 1. Amplification was carried out in a Mastercycler (Eppendorf, Hamburg, Germany). PCR was performed in a $25 \mu \mathrm{L}$ reaction mixture containing 50-100 ng DNA template, $2.5 \mu \mathrm{L} 10 \times$ reaction buffer (Thermo Fisher Scientific, Vilnius, Lithuania), $200 \mu \mathrm{mol} \mathrm{L}^{-1}$ of each dNTP, $2.5 \mathrm{mmol} \mathrm{L}^{-1} \mathrm{MgCl}_{2}$, 0.5- $\mathrm{mmol} \mathrm{L}^{-1}$ of each primer, and 0.5-U Taq polymerase (Thermo Fisher Scientific). The amplification products were separated on a $1.5-3.0 \%$ agarose gel stained with ethidium bromide and photographed. Amplicons were purified using NucleoSpin ${ }^{\circledR}$ Extract II (Macherey-Nagel, Düren, Germany) and sequenced at Eurofins Genomics (Ebersberg, Germany). Sequence alignment was carried out with ClustalW software. The BLAST algorithm was used to determine the most relate sequence relatives in the National Centre for Biotechnology Information nucleotide sequence database (http://www.ncbi.nlm.nih. gov/BLAST). The $16 S$ rRNA gene restriction digestion was carried out employing AluI, CfoI, and DraI (Thermo Fisher Scientific), according to the supplier's instructions. The products of the PCR-amplified Internal Transcribed
Spacers ITS region were digested with the restriction endonucleases HinfI and TaqI. Restriction digests were subsequently analyzed by agarose electrophoresis, as above reported.

\section{Molecular fingerprinting of lactic acid bacteria}

LAB strains were typed by random amplification of polymorphic DNA-PCR (RAPD) typing with primers M13 (5'-GAGGGTGGCGGTTCT-3') and LP1 (5'ACGCGCCCT- $\left.3^{\prime}\right)$. An annealing temperature of 38 and $48{ }^{\circ} \mathrm{C}$ for M13, and LP1 respectively, and an amplification protocol of 35 cycles were used. The PCR products were analyzed by electrophoresis and photographed as reported earlier. Grouping of the RAPD-PCR profiles was obtained with the BioNumeric 5.0 software package (Applied Maths, Kortrijk, Belgium), following the unweighted pair-group method with arithmetic averages cluster analysis. The value for the reproducibility of the assay, evaluated by the analysis of repeated DNA extracts of representative strains was $>93 \%$.

\section{Carbohydrate utilization}

The utilization of different carbon sources was carried out using a basal medium (containing Peptone 1,5\% wt $/ \mathrm{v}$, Yeast extract $0.6 \% \mathrm{wt} / \mathrm{v}$, chlorophenol red $0.004 \% \mathrm{wt} / \mathrm{v}$,

Table 1 PCR primers and conditions used for isolates identification

\begin{tabular}{|c|c|c|c|c|c|}
\hline Primers & Target & Sequence $\left(5^{\prime}-3^{\prime}\right)$ & Thermal conditions & $\begin{array}{l}\text { Amplicon } \\
\text { (bp) }\end{array}$ & References \\
\hline $\begin{array}{l}\text { RSA_F } \\
\text { RSA_R }\end{array}$ & $\begin{array}{l}16 S-23 S \text { rDNA spacer } \\
\text { region (RSA) }\end{array}$ & $\begin{array}{l}\text { GAAGTCGTAACAAGG } \\
\text { CAAGGCATCCACCGT }\end{array}$ & $\begin{array}{l}94^{\circ} \mathrm{C} \times 45 \mathrm{~s} \\
54^{\circ} \mathrm{C} \times 1 \mathrm{~min} \times 35 \text { cycles }\end{array}$ & Variable & Lane (1991) \\
\hline $\begin{array}{l}16 S \_F \\
16 S \_R\end{array}$ & 165 rDNA gene & $\begin{array}{l}\text { AGAGTTTGATCCTGGCTCAG } \\
\text { CTACGGCTACCTTGTTACGA }\end{array}$ & $\begin{array}{l}94^{\circ} \mathrm{C} \times 45 \mathrm{~s} \\
55^{\circ} \mathrm{C} \times 45 \mathrm{~s} \times 35 \text { cycles }\end{array}$ & 1540 & Lane (1991) \\
\hline $\begin{array}{l}\text { p8FLP } \\
\text { p806R }\end{array}$ & Partial 165 rDNA gene & $\begin{array}{l}\text { AGTTTGATCCTGGCTCAG } \\
\text { GGACTACCAGGGTATCTAAT }\end{array}$ & $\begin{array}{l}94^{\circ} \mathrm{C} \times 1 \mathrm{~min} \\
56^{\circ} \mathrm{C} \times 1 \mathrm{~min} \times 30 \text { cycles }\end{array}$ & 800 & McCabe et al. (1995) \\
\hline $\begin{array}{l}\text { L.plant_F } \\
\text { L.plant_R }\end{array}$ & L.plantarum & $\begin{array}{l}\text { CCGTTTATGCGGAACACC } \\
\text { TCGGGATTACCAAACATCAC }\end{array}$ & $\begin{array}{l}94^{\circ} \mathrm{C} \times 2 \mathrm{~min} \\
56^{\circ} \mathrm{C} \times 1 \mathrm{~min} \times 35 \text { cycles }\end{array}$ & 318 & Torriani et al. (2001) \\
\hline $\begin{array}{l}\text { Pedio23S_F } \\
\text { Pedio23S_R }\end{array}$ & Pediococcus spp. & $\begin{array}{l}\text { GAACTCGTGTACGTTGAAAAGTGCTGA } \\
\text { GCGTCCCTCCATTGTTCAAACAAG }\end{array}$ & $\begin{array}{l}94^{\circ} \mathrm{C} \times 45 \mathrm{~s} \\
64^{\circ} \mathrm{C} \times 1 \mathrm{~min} \times 35 \text { cycles }\end{array}$ & 701 & $\begin{array}{l}\text { Pfannebecker and } \\
\text { Fröhlich (2008) }\end{array}$ \\
\hline $\begin{array}{l}\text { P23S_R } \\
\text { PPE23S_F }\end{array}$ & P.pentosaceus & $\begin{array}{l}\text { CTGTCTCGCAGTCAAGCTC } \\
\text { CCAGGTTGAAGGTGCAGTAAAAT }\end{array}$ & $\begin{array}{l}94^{\circ} \mathrm{C} \times 1 \mathrm{~min} \\
67^{\circ} \mathrm{C} \times 1 \mathrm{~min} \times 35 \text { cycles }\end{array}$ & 1640 & $\begin{array}{l}\text { Pfannebecker and } \\
\text { Fröhlich (2008) }\end{array}$ \\
\hline $\begin{array}{l}\text { P23S-R } \\
\text { ArgentF }\end{array}$ & P. argentinicus & $\begin{array}{l}\text { CTGTCTCGCAGTCAAGCTC } \\
\text { GATATTCCTGTACTAGTTAGAT }\end{array}$ & $\begin{array}{l}94^{\circ} \mathrm{C} \times 1 \mathrm{~min} \\
60^{\circ} \mathrm{C} \times 1 \mathrm{~min} \times 35 \text { cycles }\end{array}$ & 948 & This study \\
\hline $\begin{array}{l}\text { Lbrev } \\
1391 F\end{array}$ & L.brevis & $\begin{array}{l}\text { TAATGATGACCTTGCGGTC } \\
\text { TGTACACACCGCCCGTC }\end{array}$ & $\begin{array}{l}94^{\circ} \mathrm{C} \times 45 \mathrm{~s} \\
48^{\circ} \mathrm{C} \times 45 \mathrm{~s} \times 35 \text { cycles }\end{array}$ & 330 & Coton et al. (2008) \\
\hline $\begin{array}{l}\text { Weiss_F } \\
\text { Weiss_R }\end{array}$ & Weissella spp. & $\begin{array}{l}\text { CGTGGGAAACCTACCTCTTA } \\
\text { CCCTCAAACATCTAGCAC }\end{array}$ & $\begin{array}{l}94^{\circ} \mathrm{C} \times 45 \mathrm{~s} \\
54^{\circ} \mathrm{C} \times 1 \mathrm{~min} \times 35 \text { cycles }\end{array}$ & 725 & Jang et al. (2002) \\
\hline $\begin{array}{l}1 \mathrm{RL} \\
\text { LaccreR }\end{array}$ & L. lactis & $\begin{array}{l}\text { TTTGAGAGTTTGATCCTGG } \\
\text { GGGATCATCTTTGAGTGAT }\end{array}$ & $\begin{array}{l}94^{\circ} \mathrm{C} \times 2 \mathrm{~min} \\
54^{\circ} \mathrm{C} \times 1 \mathrm{~min} \times 35 \text { cycles }\end{array}$ & 238 & Pu et al. (2002) \\
\hline $\begin{array}{l}\text { LeuclacF } \\
\text { LeuclacR }\end{array}$ & L. lactis & $\begin{array}{l}\text { AGGCGGCTTACTGGACAAC } \\
\text { CTTAGACGGCTCCTTCCAT }\end{array}$ & $\begin{array}{l}94^{\circ} \mathrm{C} \times 2 \mathrm{~min} \\
58^{\circ} \mathrm{C} \times 1 \mathrm{~min} \times 35 \text { cycles }\end{array}$ & 742 & Lee et al. (2000) \\
\hline $\begin{array}{l}\text { ITS1 } \\
\text { ITS4 }\end{array}$ & $\begin{array}{l}\text { ITS1-5.8S-ITS2 Internal Tran- } \\
\text { scribed Spacer (ITS) }\end{array}$ & $\begin{array}{l}\text { TCCGTAGGTGAACCTGCGG } \\
\text { TCCTCCGCTTATTGATATGC }\end{array}$ & $\begin{array}{l}94^{\circ} \mathrm{C} \times 45 \mathrm{~s} \\
60^{\circ} \mathrm{C} \times 1 \mathrm{~min} \times 35 \text { cycles }\end{array}$ & Variable & $\begin{array}{l}\text { Jespersen et al. } \\
\text { (2005) }\end{array}$ \\
\hline $\begin{array}{l}\mathrm{NL} 1 \\
\mathrm{NL} 4\end{array}$ & 265 rDNA gene & $\begin{array}{l}\text { GCATATCAATAAGCGGAGGAAAAG } \\
\text { GGTCCGTGTTTCAAGACGG }\end{array}$ & $\begin{array}{l}94^{\circ} \mathrm{C} \times 2 \mathrm{~min} \\
52^{\circ} \mathrm{C} \times 1 \mathrm{~min} \times 35 \text { cycles }\end{array}$ & 778 & $\begin{array}{l}\text { Kurtzman and } \\
\text { Robnett (1998) }\end{array}$ \\
\hline
\end{tabular}


Tween $801 \mathrm{ml} \mathrm{L}^{-1}, \mathrm{pH}$ 6.4) and the desired filter-sterilized carbohydrate at a final concentration of $0.5 \%(\mathrm{wt} / \mathrm{v})$.

\section{$\mathrm{pH}$ measurement}

Measurement of $\mathrm{pH}$ was determined on $10 \mathrm{~g}$ of fermented bran suspended in $100 \mathrm{~mL}$ of distilled water by a $\mathrm{pH}$ meter (PHM 250, Radiometer, Copenhagen, Denmark).

\section{Statistical analysis}

All data are reported as mean \pm standard deviation. Oneway ANOVA was performed on chemical data; if significant $(p<0.05)$ effects were found, pairwise comparisons between samples were checked with Tukey's test (Statgraphics XV version 15.1.02, StatPoint Inc., Warrenton, VA, USA).

\section{Nucleotide sequence accession numbers}

The $16 S$ rDNA sequences determined during the present study have been deposited in the GenBank database under the accession numbers MF348245-MF348248 and MF399041-MF399049. The 26S rDNA sequences determined during the present study have been deposited in the GenBank database under the accession numbers MF348249-MF348254.

\section{Results}

\section{Microbiological analyses}

In this study, two commercial native maize brans were used to prepare spontaneous laboratory sourdoughs. The values of microbial counts as well as the $\mathrm{pH}$ during fermentation are shown in Table 2. Fermentation was characterized by a rapid increase in LAB number after the first day of bran fermentation, reaching levels of $10^{8}-10^{9}$
CFU/g, for both bran samples; these levels remained constant during all refreshment steps. The trend for the yeasts paralleled those of the LAB population throughout fermentation. From an initial concentration of $10^{2}-10^{3}$ $\mathrm{CFU} / \mathrm{g}$ an increasing and gradual growth was observed, reaching levels of $10^{7}-10^{8} \mathrm{CFU} / \mathrm{g}$, after 3-5 days of fermentation. The count was stable until the end of fermentation. The data obtained indicated that, even if the LAB count stayed higher than that of yeasts, LAB and yeasts had similar growth throughout the fermentation. Contrarily to these fermenting microorganisms, the molds population, with initial load of $10^{4} \mathrm{CFU} / \mathrm{g}$, decreased rapidly after 2-3 days of fermentation.

Referring to NLAB, they increased of about four and five $\log$ cycles in $\mathrm{C} 1$ and $\mathrm{C} 2$ fermentation respectively. This high value remained constant in $\mathrm{C} 2$ fermentation, until the end of the refreshments, while in $\mathrm{C} 1$ fermentation decreased after 9 days, at about $10^{3} \mathrm{CFU} / \mathrm{g}$. The observed different trend could be related to a lower $\mathrm{pH}$ value measured in $\mathrm{C} 1$ fermentation, which decreased from 5.1 at the beginning of the fermentation to 3.7 after two refreshment steps; it could contribute to control the growth of non-acidophilic bacteria.

\section{Molecular characterization of microbial isolates}

With the aim to characterize the natural microbial population involved in maize bran fermentation, 135 colonies of presumptive LAB were selected from different MRS plates, obtained by the analysis of the two different maize bran samples subjected to sourdough like fermentation process, as previously reported. Specifically, 68 isolates ( 36 cocci and 32 rods) from $\mathrm{C} 1$ and 67 isolates (15 cocci and 52 rods) from $\mathrm{C} 2$ samples were selected.

Table 2 Viable cell counts and pH values during spontaneous fermentation of maize bran C1 and C2

\begin{tabular}{|c|c|c|c|c|c|c|c|c|c|c|}
\hline \multirow[t]{2}{*}{ Days } & \multicolumn{5}{|c|}{ Maize bran C1 } & \multicolumn{5}{|c|}{ Maize bran C2 } \\
\hline & NLAB & Yeasts & Moulds & $L A B$ & $\mathrm{pH}$ & NLAB & Yeasts & Moulds & LAB & $\mathrm{pH}$ \\
\hline 0 & $4.5 \pm 0.2$ & $2.5 \pm 0.7$ & $3.7 \pm 0.1$ & $3.6 \pm 0.6$ & $5.1 \pm 0.1$ & $3.3 \pm 0.1$ & $2.0 \pm 0.5$ & $4.0 \pm 0.1$ & $3.1 \pm 0.3$ & $5.1 \pm 0.1$ \\
\hline 1 & $8.8 \pm 0.3$ & $4.0 \pm 0.4$ & $2.9 \pm 1.3$ & $8.8 \pm 0.1$ & $4.0 \pm 0.1$ & $7.8 \pm 0.2$ & $5.5 \pm 0.4$ & $4.7 \pm 0.1$ & $8.1 \pm 0.1$ & $5.2 \pm 0.1$ \\
\hline 2 & $8.4 \pm 1.3$ & $5.0 \pm 0.4$ & $3.8 \pm 0.3$ & $9.0 \pm 0.2$ & $3.7 \pm 0.1$ & $7.8 \pm 0.3$ & $7.8 \pm 0.3$ & $2.0 \pm 1.3$ & $9.2 \pm 0.3$ & $4.3 \pm 0.1$ \\
\hline 3 & $8.6 \pm 0.6$ & $6.1 \pm 2.2$ & $3.0 \pm 1.4$ & $9.0 \pm 0.0$ & $3.7 \pm 0.1$ & $8.2 \pm 0.3$ & $8.2 \pm 1.2$ & $2.0 \pm 0.3$ & $9.1 \pm 0.2$ & $4.3 \pm 0.1$ \\
\hline 4 & $8.4 \pm 1.5$ & $6.9 \pm 0.2$ & $2.5 \pm 0.7$ & $9.1 \pm 0.2$ & $3.7 \pm 0.1$ & $8.0 \pm 0.6$ & $8.1 \pm 0.4$ & $2.0 \pm 1.4$ & $9.0 \pm 0.2$ & $4.5 \pm 0.1$ \\
\hline 5 & $8.4 \pm 0.4$ & $7.2 \pm 0.4$ & $2.5 \pm 0.7$ & $8.8 \pm 0.1$ & $4.0 \pm 0.1$ & $7.9 \pm 1.2$ & $7.8 \pm 0.4$ & $2.0 \pm 0.7$ & $9.1 \pm 0.1$ & $4.3 \pm 0.1$ \\
\hline 6 & $7.9 \pm 0.9$ & $7.4 \pm 0.3$ & $2.5 \pm 0.7$ & $8.8 \pm 0.4$ & $3.7 \pm 0.1$ & $7.6 \pm 0.3$ & $7.8 \pm 0.2$ & $2.0 \pm 0.7$ & $8.9 \pm 0.1$ & $4.3 \pm 0.1$ \\
\hline 7 & $7.7 \pm 0.6$ & $7.7 \pm 0.0$ & $2.5 \pm 0.7$ & $9.1 \pm 0.3$ & $3.7 \pm 0.1$ & $8.0 \pm 0.4$ & $8.0 \pm 0.3$ & $2.0 \pm 0.7$ & $9.3 \pm 0.4$ & $4.3 \pm 0.1$ \\
\hline 8 & $7.6 \pm 1.8$ & $7.8 \pm 0.1$ & $2.5 \pm 0.7$ & $9.1 \pm 0.2$ & $4.0 \pm 0.1$ & $7.8 \pm 0.6$ & $7.7 \pm 0.1$ & $2.0 \pm 0.7$ & $9.2 \pm 0.2$ & $4.3 \pm 0.1$ \\
\hline 9 & $6.8 \pm 1.5$ & $7.9 \pm 0.8$ & $2.5 \pm 0.7$ & $9.0 \pm 0.1$ & $3.7 \pm 0.1$ & $7.6 \pm 1.6$ & $7.6 \pm 0.8$ & $2.0 \pm 0.7$ & $9.1 \pm 0.1$ & $4.1 \pm 0.1$ \\
\hline 10 & $3.3 \pm 1.8$ & $7.2 \pm 0.8$ & $2.7 \pm 0.4$ & $8.9 \pm 0.3$ & $3.7 \pm 0.1$ & $7.8 \pm 1.3$ & $7.8 \pm 0.5$ & $2.0 \pm 0.7$ & $9.2 \pm 0.1$ & $4.1 \pm 0.1$ \\
\hline 11 & $3.5 \pm 0.7$ & $7.6 \pm 0.0$ & $2.5 \pm 0.7$ & $8.7 \pm 0.0$ & $3.7 \pm 0.1$ & $8.1 \pm 0.8$ & $7.6 \pm 0.2$ & $2.0 \pm 0.4$ & $9.3 \pm 0.4$ & $4.1 \pm 0.1$ \\
\hline 12 & $3.3 \pm 0.4$ & $7.6 \pm 0.1$ & $2.5 \pm 0.7$ & $8.6 \pm 0.0$ & $3.7 \pm 0.1$ & $7.7 \pm 0.7$ & $7.6 \pm 0.1$ & $2.0 \pm 0.7$ & $9.2 \pm 0.1$ & $4.3 \pm 0.1$ \\
\hline
\end{tabular}


The 135 new isolates were submitted to molecular analysis for their identification. A first clustering step was reached by PCR amplification of the $16 S-23 S$ rRNA spacer region (RSA). Within 51 coccal isolates, three different profiles were obtained (Fig. 1). Clusters I and II grouped three isolates each one, whose profiles were referable to Lactococcus lactis and Leuconostoc lactis species, characterized by one band migrating approximately at 380 and $460 \mathrm{bp}$, respectively; these profiles were confirmed by species-specific amplifications (Lee et al. 2000; $\mathrm{Pu}$ et al. 2002). Cluster III grouped the majority of the coccal isolates (88\%); the RSA profile, characterized by three bands of about 310, 480, $500 \mathrm{bp}$, was associated to Pediococcus genus. A genus-specific PCR showed positive signals for all 45 isolates (Pfannebecker and Fröhlich 2008). Through $16 S$ rRNA analysis of representative strains of the cluster, specific PCR for P. pentosaceus (Pfannebecker and Fröhlich 2008) and a PCR assays developed in this study for identification of P. argentinicus (based on primer set designed within variable regions of $23 \mathrm{~S}$ rRNA gene (Table 1), seven strains have been ascribed to $P$. argentinicus species and the remaining 38 isolates to $P$. pentosaceus. $P$. argentinicus, isolated from Argentinean wheat flour is a described species of Pediococcus, showing a high phylogenetic relatedness with $P$. pentosaceus (De Bruyne et al. 2008). Figure 2a shows the RAPD-PCR banding patterns of the 45 Pediococcus isolates; a high degree of genetic variability can be observed.

The $84 \mathrm{rod}$ isolates were grouped in three different clusters (IV, V, VI in Fig. 1). Clusters IV and V included 29 and 8 isolates respectively, whose characteristic profiles for the species Lactobacillus plantarum and L. brevis have been confirmed by species-specific amplifications (Torriani et al. 2001; Coton et al. 2008). Their RAPD profiles are presented in Fig. 2b. Differently from the high polymorphism found in Pediococcus, the degree of intraspecies variability in $L$. plantarum was very low, despite

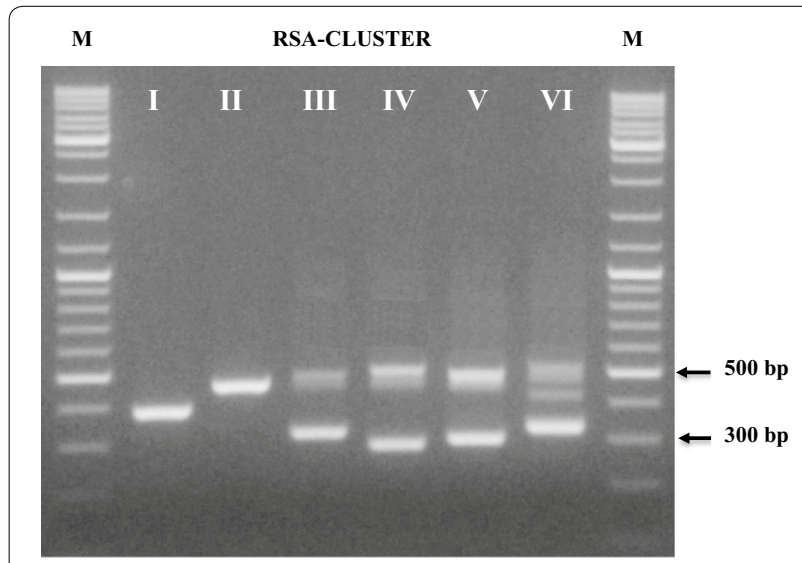

Fig. 1 RSA profiles of representative $L A B$ isolates of each cluster obtained. M: DNA ladder mix the isolates came from two different samples of bran and from different refreshments. Cluster VI grouped 47 isolates with a RSA profile constituted by three bands of about 340, 440 and 530 bp: $16 S$ rRNA sequencing of a representative strain of the cluster indicated the belonging to the species Weissella confusa. A subsequent genusspecific PCR (Jang et al. 2002) showed positive signals for all 47 isolates. Since no species-specific probes are available for the identification of Weissella species, we carried out $\mathrm{L}$-arabinose utilization test and a restriction analysis of the $16 \mathrm{~S} \mathrm{rDNA}$ with restriction endonucleases able to underline the polymorphism existing within the gene of related species (AluI, DraI and CfoI) (Table 3). The results obtained permitted to ascribe 12 isolates to $W$. confusa ( $\mathrm{L}$-arabinose negative) and 35 isolates to $W$. cibaria (L-arabinose positive), the species most phylogenetically related to $W$. confusa. Their differentiation was also obtained by RAPD-PCR experiments with primer LP1 (Fig. 2c).

A total of 12 NLAB isolates were collected from CASO agar plates. The isolates from the refreshments of dough $\mathrm{C} 1$ belonged to the Gram negative Acetobacter genus, being $A$. cibinongensis (two strains) and A. orientalis (one strain) the isolated species, along with Enterobacteriaceae, primarily Enterobacter asburiae (two strains), E. ludwigii (one strain), E. cloacae (one strain) and then Escherichia coli (one strain). Differently, NLAB identification from the doughs of maize bran $\mathrm{C} 2 \mathrm{dem}$ onstrated a representative presence of Gram positive bacteria belonging to Staphylococcus genus, being $S$. warneri (two strains) and S. pasteuri (one strain) the isolated species.

The next step was the identification of the 93 yeast isolates ( 51 from $\mathrm{C} 1$ and 42 from C2). Also in this case a first clustering has been obtained through the amplification of the Internal Transcribed Spacers. Four clusters were distinguishable: cluster I grouped five isolates with a PCR product of $440 \mathrm{bp}$, cluster II 32 isolates with a PCR product of $600 \mathrm{bp}$, cluster III 12 isolates with a PCR product of $720 \mathrm{bp}$ and cluster IV 44 isolates with a PCR product of $740 \mathrm{bp} .26 \mathrm{~S}$ rDNA gene sequencing of representative strains of each cluster allowed to ascribe the isolates of the four clusters to the species Pichia fermentans, Wickerhamomyces anomalus, Kluyveromyces marxianus and Kazachstania unispora, respectively. A further digestion of the amplified ITS products with TaqI and HinfI, permitted the obtainment of a specific restriction profile for all isolates of the same species (Table 3).

Finally, three representative fungal isolates were identified as Mucor circinelloides, Mucor irregularis and Fusarium verticillioides. These fungal species, causing several diseases and producing a wide range of mycotoxins, have been associated with various cereal crops and processed 


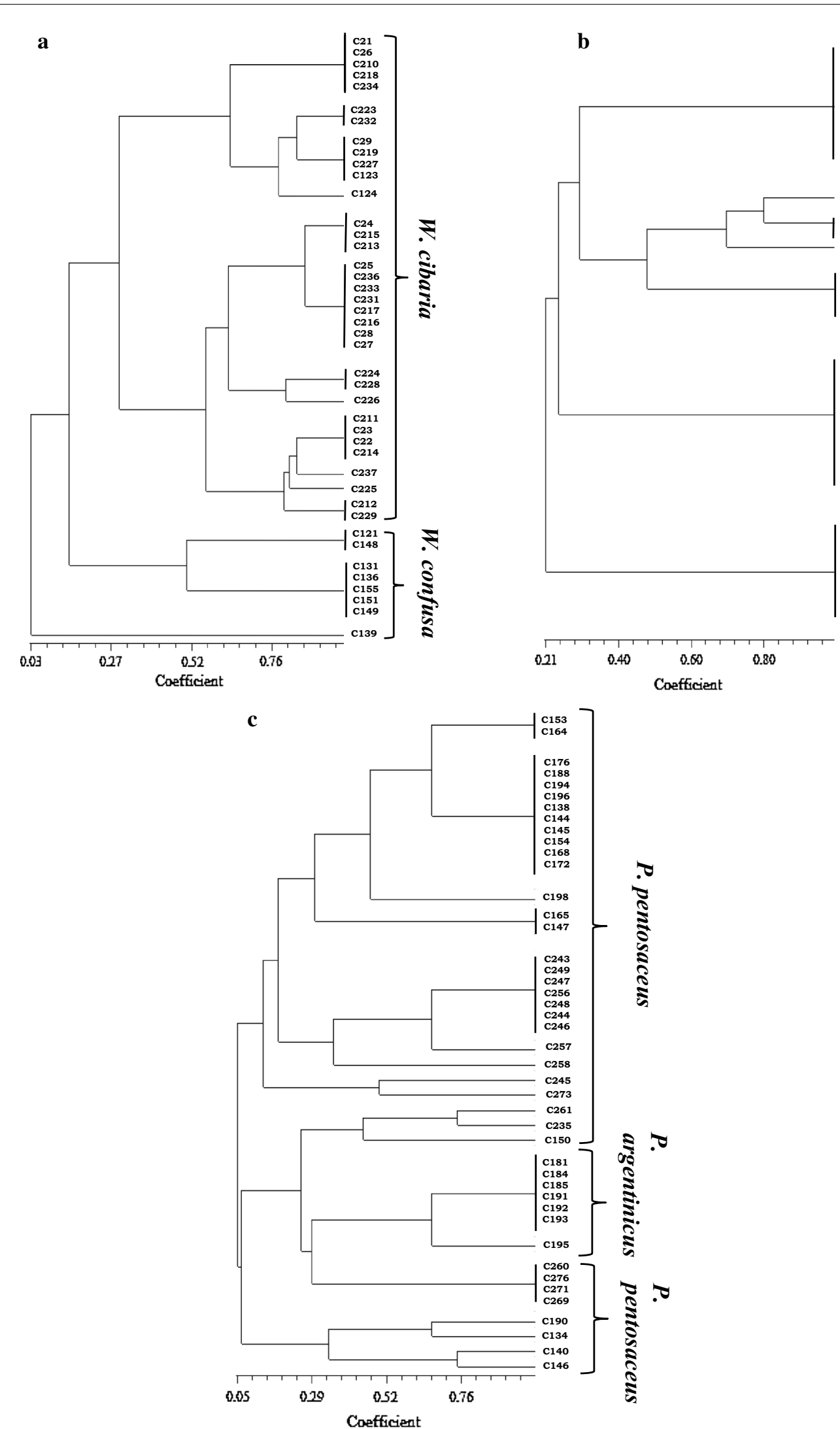

Fig. 2 RAPD-PCR profiles of $L A B$ isolated during maize bran sourdoughs fermentation. Primers M13 (a, b) and LP1 (c) 
Table 3 Restriction patterns obtained for differentiation of Weissella sp. (a) and yeasts (b) isolated from maize bran fermentation

\begin{tabular}{|c|c|c|c|}
\hline \multirow{2}{*}{$\begin{array}{l}65 \text { rDNA (bp) } \\
\text { (Weiss_F-Weiss_R) }\end{array}$} & \multicolumn{2}{|c|}{ Restriction fragments (bp) } & \multirow[t]{2}{*}{ Assigned species } \\
\hline & Dral & Alul & \\
\hline \multicolumn{4}{|l|}{ (a) } \\
\hline 727 & $639+88$ & $370+222+135$ & W. cibaria \\
\hline 727 & 727 & $505+222$ & W. confusa \\
\hline \multirow[t]{2}{*}{ ITS1-ITS4 (bp) } & \multicolumn{2}{|c|}{ Restriction fragments (bp) } & Assigned species \\
\hline & Hinfl & Taql & \\
\hline \multicolumn{4}{|l|}{ (b) } \\
\hline 740 & $366+374$ & $321+138+116+106$ & K. unispora \\
\hline 589 & $301+288$ & $304+285$ & W. anomalus \\
\hline 725 & $245+180+110+70$ & $300+245,190$ & K. marxianus \\
\hline
\end{tabular}

grains (Murillo-Williams and Munkvold 2008; Pitt and Hocking 2009).

\section{Dynamics of microbial population during fermentation}

Species composition and LAB and yeasts succession during the fermentation of the two samples of maize bran are reported in Fig. 3. As shown, the fermentation of both bran samples was characterized by a microbial succession. The initial stage of the fermentation was characterized by co-dominance of Weissella sp. and Pediococcus sp. in C1 sample and predominance of Weissella sp. in $\mathrm{C} 2$ sample. W. anomalus was the dominant yeast species in both fermentations. At the refreshment step 7, a natural selection was produced, with the disappearing of Weissella in both samples and the presence of $L$. plantarum (53\% of the isolates in $\mathrm{C} 1$ and $45 \%$ in $\mathrm{C} 2$ samples), who became the main species in C2 (69\%) at refreshment step 12. In $\mathrm{C} 1$ samples a concomitant presence of $L$. brevis was observed. P. pentosaceus/argentinicus occurred at all stage of refreshment, even if with different incidence. Regarding yeast succession, $W$. anomalus disappeared from the community, while K. unispora was subsequently detected. In $\mathrm{C} 1$ fermentation this was the only yeast found at the end of the fermentation; in $\mathrm{C} 2$ sample a significant presence of $K$. marxianus (56\% and $19 \%$ at refreshment steps 7 and 12 respectively) was also observed.

Characterization of native maize bran and fermented bran Table 4 reports the proximate composition detected in native and fermented samples. In native maize bran $\mathrm{C} 2$, ash, protein and sugars content was significantly $(p<0.05)$ higher than in $\mathrm{C} 1$, differences that could probably be related to cultivars and pedo-climatic conditions (Sokrab et al. 2011). At the end of the sourdough-like fermentation process (refreshment 12), both the tested brans contained slightly higher amounts of lipid and significantly lower $(p<0.05)$ protein levels from native sample only for $\mathrm{C} 2$. As expected, sourdough-like fermentation resulted in a significant $(p<0.05)$ decrease of the total content of sugars. On the other hand, this process induces a threefold significant $(p<0.05)$ increase in soluble dietary fiber in both $\mathrm{C} 1$ and $\mathrm{C} 2$ samples, without affecting their insoluble fraction. Regarding TOTAX, the results obtained suggest that bran sourdough-like fermentation contribute to their solubilization, with a significant $(p<0.05)$ reduction of this hemicellulosic fraction, accompanied only by a slight increase of WEAX. The arabinose to xylose ratio in WEAX, an indicator of the average degree of arabinose substitution (avDAS), showed a little reduction, indicating that, in both fermented brans, WEAX were slightly less substituted with arabinose than those present in the native brans (Damen et al. 2011; Broekaert et al. 2011). The levels of FFA detected in C1 and $\mathrm{C} 2$ maize bran before and after sourdough-like fermentation are shown in Fig. 4. The concentration of FFA assessed in native brans was not statistically different $(0.7 \pm 0.2$ and $1.6 \pm 0.4 \mathrm{mg} / 100 \mathrm{~g}$ for $\mathrm{C} 1$ and $\mathrm{C} 2$ respectively) and showed a significant $(p<0.05)$ increase after the sourdough-like fermentation (two- and fivefold in C2 and $\mathrm{C} 1$ respectively). Phytate is known to chelate several nutritionally essential nutrients and can negatively influence the activity of digestive enzymes by the chelation of mineral cofactors or by interacting with protein. In accordance with our previous study on wheat (Manini et al. 2014) the sourdough-like fermentation process promoted a degradation of phytic acid (Fig. 5) also in maize brans. In particular, this antinutrient compound was significantly reduced of about $50 \%$ in both $\mathrm{C} 1$ and $\mathrm{C} 2$, likely 

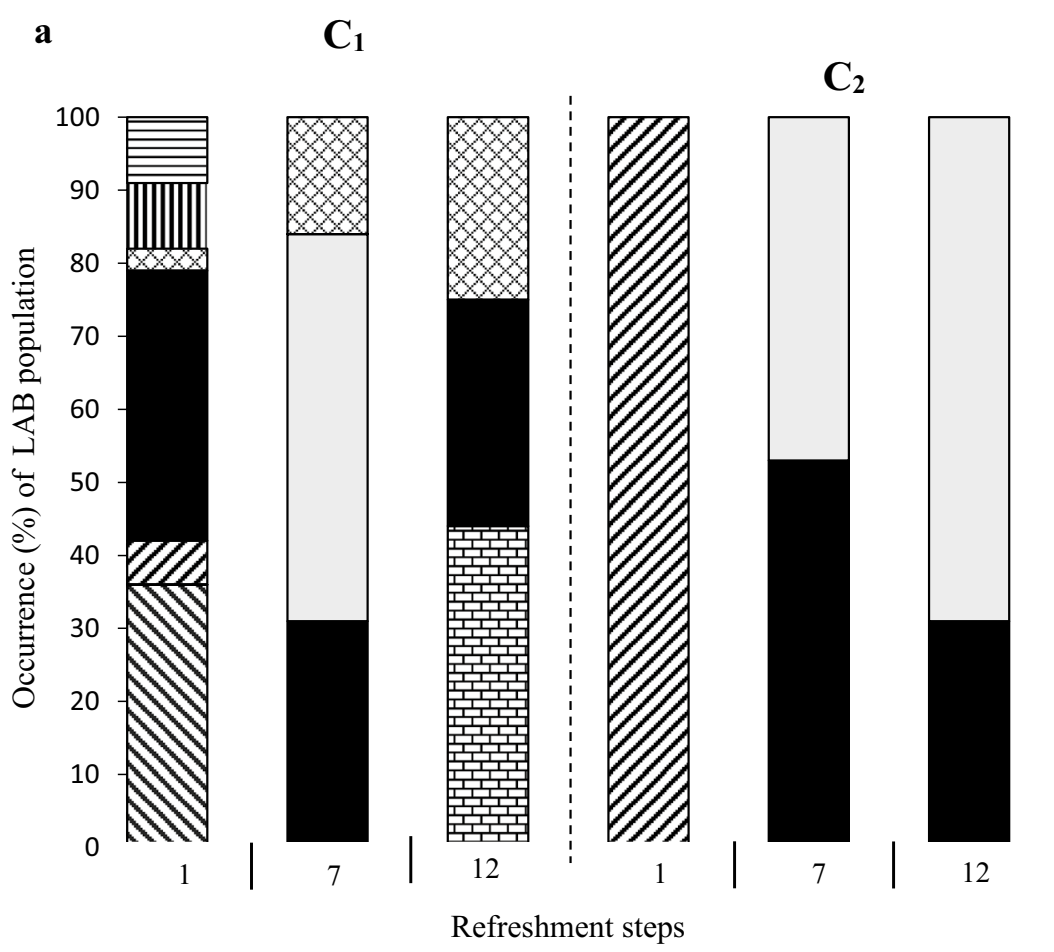

目 Leuc. lactis

III L. lactis

园 L. brevis

$\square$ L. plantarum

- P. pentosaceus

国 $P$. argentinicus

W. cibaria

W. confusa

b

$\mathrm{C}_{1}$

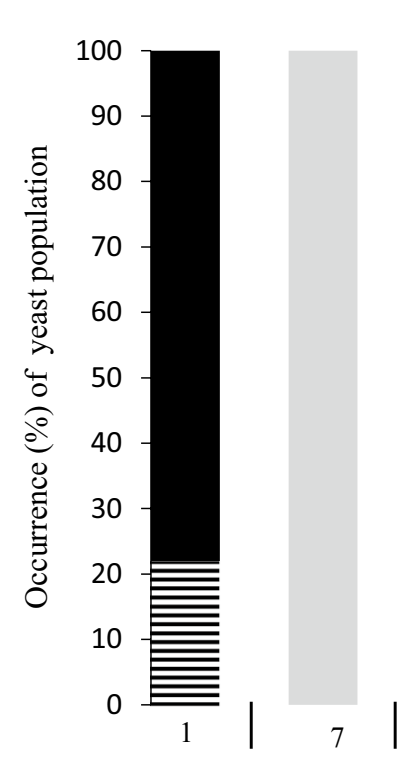

$\mathrm{C}_{2}$

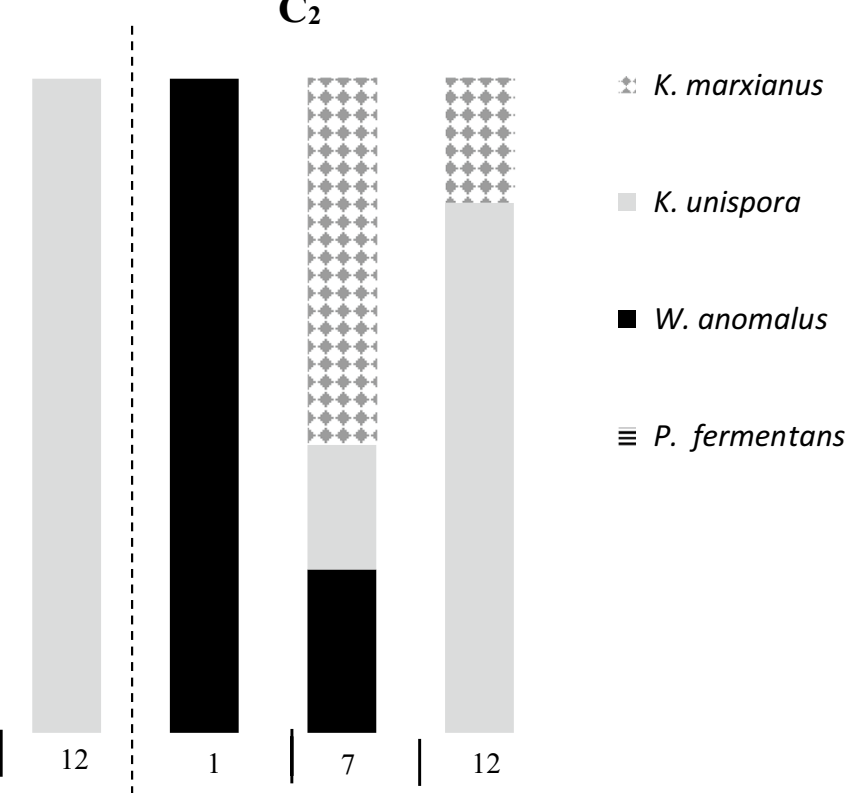

Refreshment steps

Fig. 3 Changes in community structure of lactic acid bacteria (a) and yeasts (b) during sourdough-like fermentation of the two maize bran samples (C1 and C2) 
Table 4 Chemical composition (mean \pm SD; expressed as \% of dry weight) of native and fermented (refreshment 12) brans

\begin{tabular}{lllll}
\hline & Native maize bran C1 & Fermented maize bran C1 & Native maize bran C2 & Fermented maize bran C2 \\
\hline Ash & $0.9 \pm 0.0 \mathrm{a}$ & $1.1 \pm 0.0 \mathrm{a}$ & $2.2 \pm 0.1 \mathrm{~b}$ & $1.8 \pm 0.2 \mathrm{c}$ \\
Proteins & $6.4 \pm 0.3 \mathrm{a}$ & $7.2 \pm 0.2 \mathrm{a}$ & $9.0 \pm 0.3 \mathrm{~b}$ & $7.7 \pm 0.5 \mathrm{a}$ \\
Lipids & $2.7 \pm 0.0$ & $4.2 \pm 0.1$ & $3.5 \pm 0.8$ & $4.6 \pm 0.2$ \\
Sugars & $1.7 \pm 0.1 \mathrm{a}$ & $0.2 \pm 0.0 \mathrm{~b}$ & $4.3 \pm 0.4 \mathrm{c}$ & $0.5 \pm 0.0 \mathrm{~b}$ \\
Glucose & $0.3 \pm 0.0$ & $0.2 \pm 0.0$ & $2.6 \pm 0.2$ & $0.2 \pm 0.0$ \\
Fructose & $0.3 \pm 0.0$ & $\mathrm{nd}$ & $1.4 \pm 0.2$ & $0.2 \pm 0.0$ \\
Sucrose & $1.2 \pm 0.1$ & $\mathrm{nd}$ & $\mathrm{nd}$ & $\mathrm{nd}$ \\
Maltose & $\mathrm{nd}$ & $36.0 \pm 1.8$ & $0.4 \pm 0.0$ & $\mathrm{nd}$ \\
Insoluble fiber & $35.2 \pm 3.0$ & $1.7 \pm 0.4 \mathrm{~b}$ & $41.2 \pm 3.7$ & $45.6 \pm 1.6$ \\
Soluble fiber & $0.6 \pm 0.1 \mathrm{a}$ & $13.1 \pm 0.1 \mathrm{~b}$ & $0.7 \pm 0.2 \mathrm{a}$ & $2.3 \pm 0.3 \mathrm{~b}$ \\
Total arabinoxylans (TOTAX) & $20.1 \pm 1.5 \mathrm{a}$ & 0.74 & $21.3 \pm 1.1 \mathrm{a}$ & $10.6 \pm 1.2 \mathrm{~b}$ \\
Arabinose/xylose in TOTAX & 0.75 & $0.3 \pm 0.0$ & 0.70 & 1.28 \\
Sol. arabinoxylans (WEAX) & $0.1 \pm 0.0$ & 1.07 & 2.98 & $0.2 \pm 0.0$ \\
Arabinose/xylose in WEAX & 1.43 & & 2.35 \\
\hline
\end{tabular}

Data in the same row not sharing common letters are significantly different $(p<0.05)$

nd not detectable

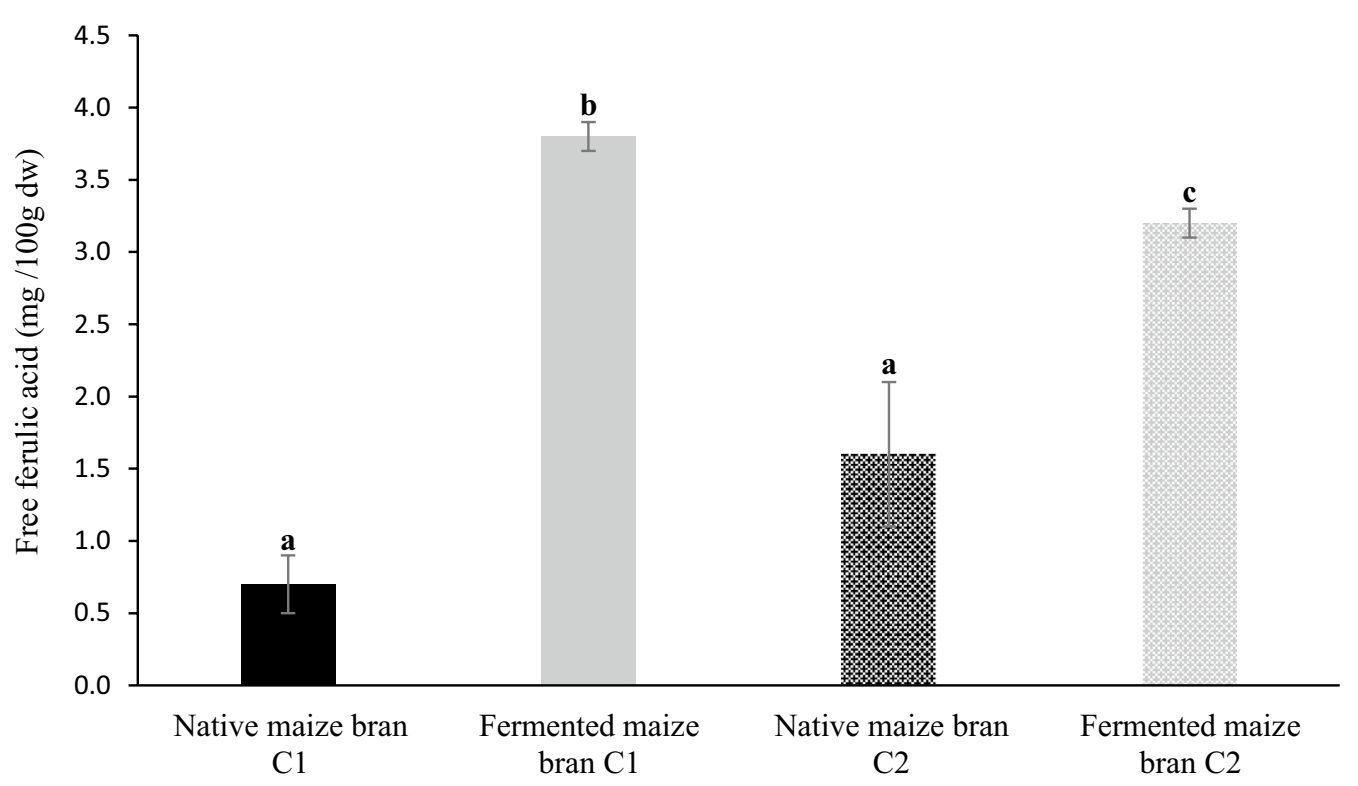

Fig. 4 Free ferulic acid (mean \pm SD; expressed as mg/100 g of dry weight) content in native and fermented (refreshment 12 ) brans. Bars not sharing common letters are significantly different $(p<0.05)$

through the activation of microbial and endogenous phytases.

\section{Discussion}

The continuous search for functional ingredients providing health effects and the possibility to take advantage of agro-industrial by-products have attracted great interest in using bran-enriched products. In this research, a polyphasic approach has been carried out to characterize at microbiological and chemical level maize bran in order to enhance its technological and nutritional properties.

Little data are available in literature on microbial composition of maize and maize bran: to our knowledge up to now researches were carried out on the evolution of fermenting microbiota in wheat or rye brans (Katina et al. 2007; Manini et al. 2014) and in ethnic food products, 


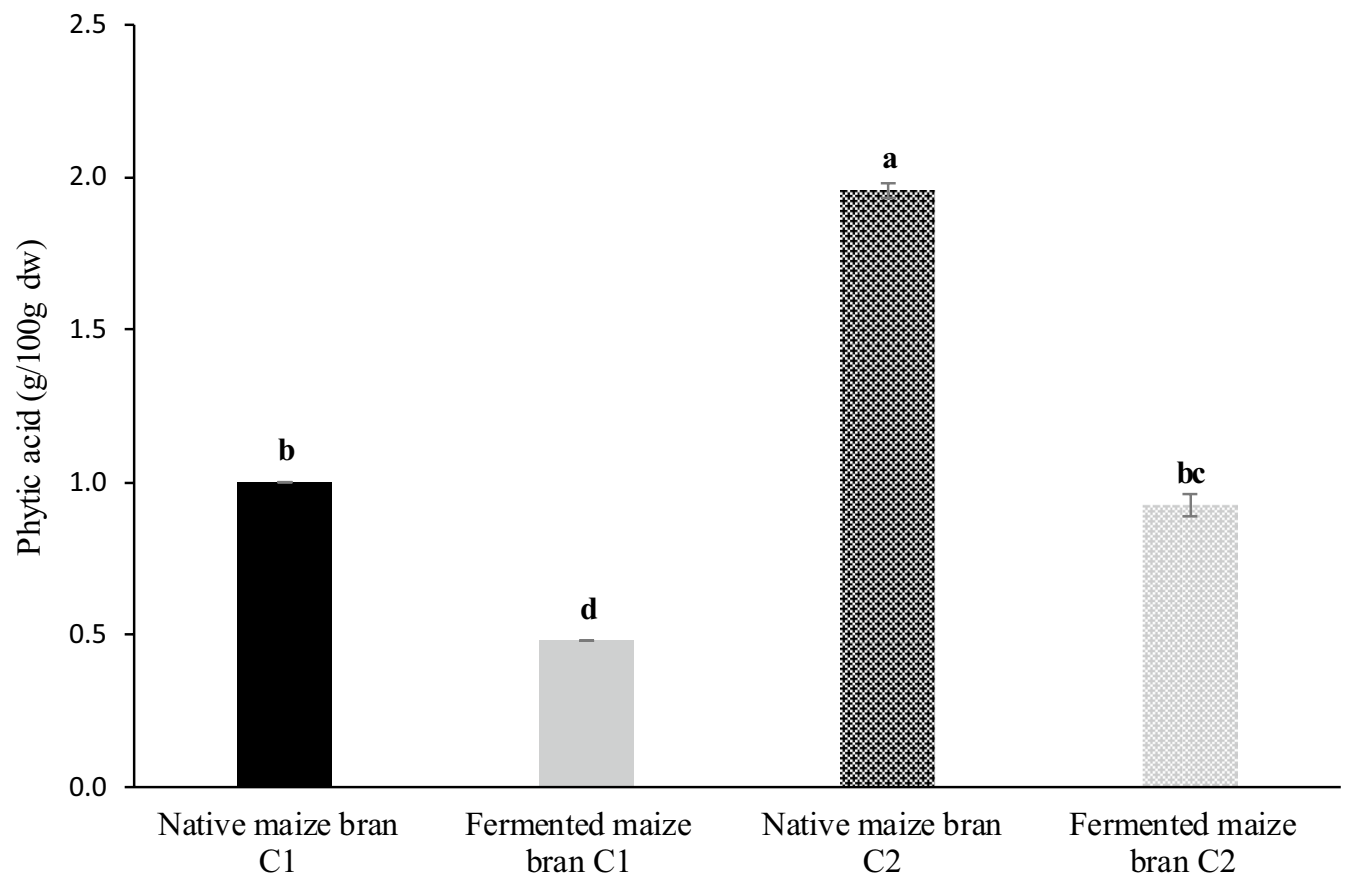

Fig. 5 Phytic acid (mean \pm SD; expressed as $\mathrm{g} / 100 \mathrm{~g}$ of dry weight) content in native and fermented (refreshment 12) brans. Bars not sharing common letters are significantly different $(p<0.05)$

such as tarhana (Settanni et al. 2011). Very lacking information exists on microbial population during maize bran fermentation. In our study, microbial population colonizing the first steps of natural fermentation of maize bran is characterized by a predominance of species belonging to the Pediococcus and Weissella genus. These physiological groups have also been selected during maize-based spontaneously fermented doughs produced in West African countries (Oguntoyinbo et al. 2011; Okeke et al. 2015; Assohoun-Djeni et al. 2016). Even if little data are available, this microbial population could be considered maize/ maize bran endogenous.

During daily propagation of sourdoughs, $L$. plantarum became the main LAB species. L. plantarum is a versatile and competitive species, that can adapt to different environmental conditions (Minervini et al. 2010) and these features can explain its presence, as member of the complex microbiota, in many sourdoughs (De Vuyst et al. 2014). The interest dedicated to this species, particularly in the bakery sector, is related to the ability of producing antimicrobial compounds, especially antifungal metabolites (Crowley et al. 2013).

During the maize bran fermentation, we found several species of yeasts, some of who predominate in the first step of fermentation, as $W$. anomalus, other at the end of the refreshments, as $K$. unispora. This is the first report on association between LAB and yeasts in maize bran fermentation process. W. anomalus was shown to inhibit the growth of fungi in airtight-stored cereal grains (Coda et al. 2011). Its presence in maize bran sourdoughs, in association with $L$. plantarum could explain the decrease of vital molds we observed during fermentation. $K$. unispora plays a significant role both in cheese ripening and in fermented milk production; it has been documented to exist in few sourdough ecosystems, as artisan wheat and rye sourdough albeit in low abundance (Bessmeltseva et al. 2014). On the contrary, our data suggest that this species can be considered representative of the yeast microbiota selected during maize bran refreshment steps.

Evident differences in dominant NLAB were found between $\mathrm{C} 1$ and $\mathrm{C} 2$ samples; this could be a consequence of differences in the environmental conditions (i.e., temperature, water, and maize provenance) and in the evolution of dough $\mathrm{pH}$; this parameter has a strong and decisive influence on the control and selection of bacteria. Among the identified NLAB, the family Enterobacteriaceae was the predominant in $\mathrm{C} 1$ doughs, followed by Acetobacter genus, differently from the doughs C2 where Staphylococcus genus was the prevalent. Regarding Enterobacteriaceae, strains of $E$. asburiae were previously identified among thermotolerant wheat associated bacteria from a peninsular zone of India (Verma et al. 2016) and one E. ludwigii strain isolated from Lolium perenne rhizosphere showed plant growth promoting 
properties (Shoebitz et al. 2009). The genus Acetobacter has been previously reported to dominate, together with the genus Lactobacillus, the first step of fermentation of whole crop maize silage (Sträuber et al. 2012). Different species of the genus Acetobacter were also found in a preliminary study to explore the bacterial microbiota in Colombian maize fermented dough Masa Agria (ChavezLopez et al. 2016). Lactic and acetic acid provide sour taste in maize, but, at the same time, these fermentation products promote the activation of the phytases naturally present in grains and in bacteria, by a decrease of the $\mathrm{pH}$ value. The action of phytases plays a key role in improving nutritional value by increasing the bioavailability of essential dietary minerals. In addition, as it was observed in this study, Acetobacter species can be present in the later stage of cereal fermentation for their ability to utilize molecules other than sugars and to tolerate low $\mathrm{pH}$ conditions (Chavez-Lopez et al. 2016). Our findings on Staphylococcus isolated from C2 doughs are in agreement with other researchers who stated that Staphylococcus sp. bacteria were isolated and identified from fresh yellow grains and roots of maize in Nigeria (Orole and Adejumo 2011). Their persistence during the fermentation steps can be explained by the higher $\mathrm{pH}$ values profile of $\mathrm{C} 2$ doughs (4.3-4.1) that did not lead to selective environmental conditions.

The $\mathrm{pH}$ reduction during the process activated the enzymatic activities related to the microbial consortium characterizing spontaneous maize bran fermentation, providing a "destructuration" of the fiber fraction and a reduction of phytic acid content in both the tested brans. Moreover, the fermentation process provided for an increase in the soluble dietary fiber that can be attributed to microbial exo-polysaccharides production, as evidenced in previous studies on wheat and sorghum sourdoughs (Galle et al. 2010; Ganzle 2014). Our results also suggest that bran fermentation promoted AX solubilization since the percentage of WEAX/TOTAX was increased from $0.5 \%$ (native bran) to $2 \%$ (fermented bran). The data obtained appears interesting from a nutritional point of view, since soluble fiber positively affect post-prandial glucose metabolism and satiety (Anderson et al. 2009; Dikeman and Fahey 2006).

As already reported (Katina et al. 2006), endogenous and microbial xylanases could have a key role in fiber solubilization. Xylanase activity has been found in a $P$. fermentans strain (Madrigal et al. 2013), in Weissella spp. strains isolated from Indian fermented foods (Patel et al. 2013) and in L. plantarum and P. pentosaceus starter cultures (Laitila et al. 2006). These microorganisms were detected in all refreshment steps, suggesting a potential role of their enzymatic pool in increasing WEAX concentration, as assessed in fermented brans. Moreover, even if maize bran has been reported as a substrate resistant to enzymatic digestibility (Agger et al. 2010), our results suggest an AX "destructuration", during maize bran fermentation. These data, interesting from a functional/ nutritional point of view, deserve to be deepened by further studies.

Ferulic acid is a bioactive antioxidant compound abundant in maize bran (Zhao and Moghadasian 2008), where it is strictly cross-linked to arabinose residues in AX (Saulnier and Quemener 2009). The suggested destructuration of cell walls material, could also partly explain the increased FFA content that we assessed in fermented brans. In addition to microbial endoxylanases, other degrading enzymes, such as arabinofuranosidases, feruloyl esterases, acetyl esterases, and alpha-glucuronidases, can be involved (Grootaert et al. 2007). Even if these enzymatic activities are poorly studied in Lactobacillus genus, a few papers show the presence of feruloyl esterases in L. plantarum strains (Esteban-Torres et al. 2015) and of arabinofuranosidases in selected strains of L. brevis (Michlmayr et al. 2013).

Phytic acid is the major storage form of phosphorous comprising $1-5 \%$ by weight in cereals, located in bran fraction and pericarp in rice and wheat, and found mainly in the germ of maize kernels (Schlemmer et al. 2009). From a nutritional point of view, this compound is considered an antinutritive factor, for its ability to chelate dietary minerals, thus reducing their bioaccessibility and bioavailability. Our data show that the fermentation process promote a significant reduction of phytic acid, likely related to an activation of endogenous phytases and to the presence of specific microbial biotypes able to produce significant extracellular phytase activities.

In conclusion, the sourdough-like fermentation of maize bran seems a suitable bio-approach in promoting nutritional and functional properties of this cereal by-product. Further studies are ongoing for the characterization of the isolated microorganisms and for understanding their role in specific activities related to the enhancement of the properties of fermented maize bran as well as their safety. These studies will allow the selection of starter cultures, according to their metabolic and enzymatic activities, in order to conduct "tailored" fermentation process and improve brans or whole-meal flours from nutritional, functional and technological points of view.

\footnotetext{
Abbreviations

LAB: lactic acid bacteria; A.I.R.E.S: Associazione Italiana Essiccatori Raccoglitori Stoccatori di Cereali e Semi oleosi; AX: arabinoxylans; EFSA: European Food Safety Authority; WEAX: water-extractable arabinoxylans; AXOS: arabinoxylanoligosaccharides; XOS: xylan-oligosaccharides; TOTAX: total arabinoxylans; NLAB: non-lactic acid bacteria; PCR: polymerase chain reaction; RSA: 16S-23S rDNA spacer region; rDNA: ribosomal DNA; ITS: Internal Transcribed
} 
Spacer; BLAST: Basic Local Alignment Search Tool; RAPD: Random Amplification of Polymorphic DNA; ANOVA: analysis of variance; CFU: colony forming units; MRS: de Man, Rogosa, Sharpe; CASO: Casein-peptone Soymeal-peptone; avDAS: average degree of arabinose substitution; FFA: free ferulic acid.

\section{Authors' contributions}

GR, MGF, MB, MCC carried out the design of the study and drafted the manuscript. MD and TS carried out microbiological analyses; GR and MQ performed the molecular analyses; FM, DE, FC carried out the chemical analyses. All authors read and approved the final manuscript.

\section{Author details}

${ }^{1}$ Institute of Sciences of Food Production, National Research Council of Italy, Milan, Italy. ${ }^{2}$ Department of Food, Environmental and Nutritional Sciences, University of Milan, Milan, Italy.

\section{Acknowledgements}

The authors thank Mr. Giovanni Fiorillo for technical assistance, Molino Perteghella and Molino Spoletini for providing maize bran samples.

\section{Competing interests}

The authors declare that they have no competing interests.

\section{Availability of data and materials}

All data are fully available without restriction.

\section{Consent for publication}

Not applicable.

\section{Ethics approval and consent to participate}

No animal or human subjects were used in this work.

\section{Funding}

Not applicable.

\section{Publisher's Note}

Springer Nature remains neutral with regard to jurisdictional claims in published maps and institutional affiliations.

Received: 31 October 2017 Accepted: 7 November 2017

Published online: 16 November 2017

\section{References}

Agger J, Viksø-nielsen A, Meyer AS (2010) Enzymatic xylose release from pretreated corn bran arabinoxylan: differential effects of deacetylation and deferuloylation on insoluble and soluble substrate fractions. J Agric Food Chem 58:6141-6148

Ai Y, Jay-lin J (2016) Macronutrients in maize and human nutrition. Compr Rev Food Sci Food Saf 15:581-598

Anderson JW, Baird P, Davis RH, Ferrer S, Knudtson M, Koraym A, Waters V, Williams C (2009) Health benefits of dietary fiber. Nutr Rev 67:188-205

Assohoun-Djeni NMC, Djeni NT, Messaoudi S, Lhomme E, KoussemonCamara M, Ouassa T, Chobert J-M, Onno B, Dousset X (2016) Biodiversity, dynamics and antimicrobial activity of lactic acid bacteria involved in the fermentation of maize flour for doklu production in Côte d'Ivoire. Food Control 62:397-404

Bessmeltseva M, Viiard E, Simm J, Paalme T, Sarand I (2014) Evolution of bacterial consortia in spontaneously started rye sourdoughs during two months of daily propagation. PLOS ONE 9(4):e95449

Broekaert WF, Courtin CM, Verbeke K, Van de Wiele T, Verstraete W, Delcour JA (2011) Prebiotic and other health-related effects of cereal-derived arabinoxylans, arabinoxylan-oligosaccharides, and xylooligosaccharides. Crit Rev Food Sci Nutr 51:178-194

Chavez-Lopez C, Serio A, Delgado-Ospina J, Rossi C, Grande-Tovar CD, Paparella A (2016) Exploring the bacterial microbiota of Colombian fermented maize dough "Masa Agria" (Maiz Añejo). Front Microbiol 7:1-12. https://doi.org/10.3389/fmicb.2016.01168
Coda R, Cassone A, Rizzello CG, Nionelli L, Cardinali G, Gobbetti M (2011) Antifungal activity of Wickerhamomyces anomalus and Lactobacillus plantarum during sourdough fermentation: identification of novel compounds and long-term effect during storage of wheat bread. Appl Environ Microbiol 77:3484-3492

Coton M, Berthier F, Coton E (2008) Rapid identification of the three major species of dairy obligate heterofermenters Lactobacillus brevis, Lactobacillus fermentum and Lactobacillus parabuchneri by species-specific duplex PCR. FEMS Microbiol Lett 284:150-157

Crowley S, Mahony J, van Sinderen D (2013) Current perspectives on antifungal lactic acid bacteria as natural bio-preservatives. Trends Food Sci Technol 33:93-109

Dalié DKD, Deschamps AM, Richard-Forget F (2010) Lactic acid bacteriapotential for control of mould growth and mycotoxins: a review. Food Control 21:370-380

Damen B, Verspreet J, Pollet A, Broekaert W, Delcour JA, Courtin CM (2011) Prebiotic effects and intestinal fermentation of cereal arabinoxylans and arabinoxylan oligosaccharides in rats depend strongly on their structural properties and joint presence. Mol Nutr Food Res 55:1862-1874

De Bruyne K, Franz CMPA, Vancanneyt M, Schillinger U, Mozzi F, Font de Valdez G, De Vuyst L, Vandamme P (2008) Pediococcus argentinicus sp. nov. from Argentinean fermented wheat flour and identification of Pediococcus species by pheS, rpoA and atpA sequence analysis. Int I Syst Evol Microbiol 58:2909-2916

De Vuyst L, Van Kerrebroeck S, Harth H, Huys G, Daniel H-M, Weckx S (2014) Microbial ecology of sourdough fermentations: diverse or uniform? Food Microbiol 37:11-29

Dikeman CL, Fahey GC (2006) Viscosity as related to dietary fiber: a review. Crit Rev Food Sci Nutr 46:649-663

EFSA Panel on Dietetic Products, Nutrition and Allergies (NDA) (2011) Scientific Opinion on the substantiation of health claims related to arabinoxylan produced from wheat endosperm and reduction of post-prandial glycaemic responses (ID 830) pursuant to Article 13(1) of Regulation (EC) No 1924/2006. EFSA J 9(6):2205

Esteban-Torres M, Landete JM, Reverón I, Santamaria L, de las Rivas B, Munõz $R$ (2015) A Lactobacillus plantarum esterase active on a broad range of phenolic esters. Appl Environ Microbiol 81:3235-3242

Galle S, Schwab C, Arendt E, Ganzle M (2010) Exopolysaccharide-forming Weissella strains as starter cultures for sorghum and wheat sourdoughs. J Agric Food Chem 58:5834-5841

Ganzle MG (2014) Enzymatic and bacterial conversions during sourdough fermentation. Food Microbiol 37:2-10

Grootaert C, Delcour JA, Courtin CM, Broekaert WF, Verstraete W, Van de Wiele T (2007) Microbial metabolism and prebiotic potency of arabinoxylan oligosaccharides in the human intestine. Trends Food Sci Technol 18:64-71

Heinio RL, Noort MWJ, Katina K, Alam SA, Sozer N, de Kock HL, Hersleth M, Poutanen K (2016) Sensory characteristics of wholegrain and bran-rich cereal foods - a review. Trends Food Sci Technol 47:25-38

Jang J, Kim B, Lee J, Kim J, Jeong G, Han H (2002) Identification of Weissella species by the genus-specific amplified ribosomal DNA restriction analysis. FEMS Microbiol Lett 212:29-34

Jespersen L, Nielsen DS, Hønholt S, Jakobsen M (2005) Occurrence and diversity of yeasts involved in fermentation of West African cocoa beans. FEMS Yeast Res 5:441-453

Katina K, Salmenkallio-Marttila M, Partanen R, Forssell P, Autio K (2006) Effects of sourdough and enzymes on staling of high-fiber wheat bread. Lebensm Wiss Technol 39:479-491

Katina K, Laitila A, Juvonen R, Liukkonen KH, Kariluoto S, Piironen V, Landberg R, Aman P, Poutanen K (2007) Bran fermentation as a means to enhance technological properties and bioactivity of rye. Food Microbiol 24:175-186

Katina K, Juvonen R, Laitila A, Flander L, Nordlund E, Kariluoto S, Piironen V, Poutanen K (2012) Fermented wheat bran as a functional ingredient in baking. Cereal Chem J 89:126-134

Kurtzman CP, Robnett CJ (1998) Identification and phylogeny of ascomycetous yeasts from analysis of nuclear large subunit (26S) ribosomal DNA partial sequences. Antonie van Leeuwenhoek 73:331-371

Laitila A, Sweins H, Vilpola A, Kotavita E, Olkku J, Home S, Haikara A (2006) Lactobacillus plantarum and Pediococcus pentosaceus starter cultures as a tool for microflora management in malting and for enhancement of malt processability. J Agric Food Chem 54:3840-3851 
Lane DJ (1991) 16S/23S rRNA sequencing. In: Stackebrandt E, Goodfellow M (eds) Nucleic acid techniques in bacterial systematics. Wiley, New York, pp 115-175

Lee HJ, Park SY, Kim J (2000) Multiplex PCR-based detection and identification of Leuconostoc species. FEMS Microbiol Lett 193:243-247

Madrigal T, Maicas S, Mateo JJ (2013) Glucose and ethanol tolerant enzymes produced by Pichia (Wickerhamomyces) isolates from enological ecosystems. Am J Enol Vitic 64:126-133

Manini F, Brasca M, Plumed-Ferrer C, Morandi S, Erba D, Casiraghi MC (2014) Study of the chemical changes and evolution of microbiota during sourdough-like fermentation of wheat bran. Cereal Chem 91:342-349

McCabe KM, Khan G, Zhang YH, Mason EO, McCabe ER (1995) Amplification of bacterial DNA using highly conserved sequences: automated analysis and potential for molecular triage of sepsis. Pediatrics 95:165-169

Messia MC, Reale A, Maiuro L, Candigliota T, Sorrentino E, Marconi E (2016) Effects of pre-fermented wheat bran on dough and bread characteristics. J Cereal Sci 69:138-144

Michlmayr H, Hell J, Lorenz C, Böhmdorfer S, Rosenau T, Kneifel W (2013) Arabinoxylan oligosaccharide hydrolysis by family 43 and 51 glycosidases from Lactobacillus brevis DSM 20054. Appl Environ Microbiol 79:6747-6754

Minervini F, De Angelis M, Di Cagno R, Pinto D, Siragusa S, Rizzello CG, Gobbetti M (2010) Robustness of Lactobacillus plantarum starters during daily propagation of wheat flour sourdough type I. Food Microbiol 27:897-908

Murillo-Williams A, Munkvold GP (2008) Systemic infection by Fusarium verticillioides in maize plants grown under three temperature regimes. Plant Dis 92:1695-1700

Oguntoyinbo FA, Tourlomousis P, Gasson MJ, Narbad A (2011) Analysis of bacterial communities of traditional fermented West African cereal foods using culture independent methods. Int J Food Microbiol 145:205-210

Okeke CA, Ezekiel CN, Nwangburuka CC, Sulyok M, Ezeamagu CO, Adeleke RA, Dike SK, Krska R (2015) Bacterial diversity and mycotoxin reduction during maize fermentation (steeping) for Ogi production. Front Microbiol. https://doi.org/10.3389/fmicb.2015.01402

Orole OO, Adejumo TO (2011) Bacterial and fungal endophytes associated with grains and roots of maize. J Ecol Nat Environ 3:298-303

Patel A, Falck P, Shah N, Immerzeel P, Adlercreutz P, Stalbrand H, Prajapati JB, Holst O, Nordberg Karlsson E (2013) Evidence for xylooligosaccharide utilization in Weissella strains isolated from Indian fermented foods and vegetables. FEMS 346:20-28

Pfannebecker J, Fröhlich J (2008) Use of a species-specific multiplex PCR for the identification of pediococci. Int J Food Microbiol 128:288-296

Pitt Jl, Hocking AD (2009) Fungi and food spoilage. Springer, Berlin
Pu ZY, Dobos M, Limsowtin GK, Powell IB (2002) Integrated polymerase chain reaction-based procedures for the detection and identification of species and subspecies of the Gram-positive bacterial genus Lactococcus. J Appl Microbiol 93:353-361

Rose DJ, Inglett GE, Liu SX (2010) Utilization of maize (Zeamays) bran and maize fiber in the production of food components. J Sci Food Agric 90:915-924

Saulnier L, Quemener B (2009) Enzymatic mapping of arabinoxylan structure. In: Shewry PR, Ward JL (eds) Healthgrain methods: analysis of bioactive components in small grain cereals. AACC International, St. Paul, pp $191-201$

Schlemmer U, Frølich W, Prieto RF, Grases F (2009) Phytate in foods and significance for humans: food sources, intake, processing, bioavailability, protective role and analysis. Mol Nutr Food Res 53:S330-\$375

Settanni L, Tanguler H, Moschetti G, Reale S, Gargano V, Erten H (2011) Evolution of fermenting microbiota in Tarhana produced under controlled technological conditions. Food Microbiol 28:1367-1371

Shoebitz M, Ribaudo CM, Pardo MA, Cantore ML, Ciampi L, Curá JA (2009) Plant growth promoting properties of a strain of Enterobacter /udwigii isolated from Lolium perenne rhizosphere. Soil Biol Biochem 41:1768-1774

Sokrab AM, Mohamed Ahmed IA, Babiker EE (2011) Effect of genotype on chemical composition, total energy, antinutrients, and total and extractable minerals of maize. Int J Agric Res Rev 1:38-43

Sträuber H, Schröder M, Kleinsteuber S (2012) Metabolic and microbial community dynamics during the hydrolytic and acidogenic fermentation in a leach-bed process. Energy Sustain Soc. https://doi. org/10.1186/2192-0567-2-13

Torriani S, Felis GE, Dellaglio F (2001) Differentiation of Lactobacillus plantarum, L. pentosus, and L. paraplantarum by recA gene-derived primers. Appl Environ Microbiol 67:3450-3454

Verma P, Yadav AN, Khannam KS, Kumar S, Saxena AK, Suman A (2016) Molecular diversity and multifarious plant growth promoting attributes of Bacilli associated with wheat (Triticum aestivum $\mathrm{L}$.) rhizosphere from six diverse agro-ecological zones of India. J Basic Microbiol 56:44-58

Zhao Z, Moghadasian MH (2008) Chemistry, natural sources, dietary intake and pharmacokinetic properties of ferulic acid: a review. Food Chem 109:691-702

\section{Submit your manuscript to a SpringerOpen ${ }^{\circ}$ journal and benefit from:}

- Convenient online submission

- Rigorous peer review

- Open access: articles freely available online

- High visibility within the field

Retaining the copyright to your article

Submit your next manuscript at springeropen.com 